\title{
Changes in Enzyme Activities During Postharvest Deterioration of Green Asparagus Spears
}

\author{
P.K. Bhowmik ${ }^{1, *}$, Saikat Kumar Basu ${ }^{1}$ and A.K.M.S. Alam ${ }^{2}$ \\ ${ }^{I}$ Bioproducts and Bioprocesses Division, Lethbridge Research Centre, Agriculture and Agri-Food Canada, Lethbridge, \\ Alberta T1J 4B1, Canada and ${ }^{2}$ Department of Agricultural Extension, Khamar Bari, Farm Gate, Dhaka, Bangladesh
}

\begin{abstract}
Fresh asparagus (Asparagus officinalis L.) deteriorates rapidly after harvest. Early enzymatic changes that follow harvesting of asparagus are important factors contributing to postharvest deterioration. We held asparagus spears at $25^{\circ} \mathrm{C}$ for up to 5 days after harvest and examined changes in the activities of Acid invertase (AI), Sucrose Synthase (SS), Glutamine Synthetase (GS) and Phenylalanine ammonia Lyase (PAL) in both top and bottom portions of the spears. Soluble AI activity increased during the first day of storage and after that it decreased gradually up to five days in both top and bottom portions. Sucrose synthase activity was higher in the bottom portion than in the top; its activity declined daily for five days. Sucrose content was negatively correlated with invertase and sucrose synthase in both portions.GS enzyme activity in both top and bottom portion declined throughout the experimental period which may be related to increased ammonia accumulation. The increase in PAL activity continued until day 3 and declined thereafter.
\end{abstract}

Key Words: Ammonia, Asparagus officinalis, sugar, enzyme activity, storage.

\section{INTRODUCTION}

Asparagus (Asparagus officinalis L.) is a highly perishable vegetable that is difficult to keep fresh due to its high mechanical and physiological fragility [1]. Harvesting and handling of asparagus impose a series of stresses on the spear tissue, including wounding, separation from nutrient supply, and dehydration [2]. Fresh green asparagus deteriorates rapidly after harvest, with physiological changes including toughening, changes in flavor, and losses of chlorophyll, ascorbic acid, soluble carbohydrate, protein and amino acid [3-5]. There is evidence that 1) rapid decline of carbohydrates in the spear tip triggers or signals deterioration in the whole spear [6] and 2) spears stored at $25^{\circ} \mathrm{C}$ usually have a shorter shelf life [3]. The tip region of the spear, comprising immature, rapidly developing and growing tissue, is particularly susceptible to harvest stress and is usually the first part of the spear to show symptoms of deterioration. Within $48 \mathrm{~h}$ of harvest, respiration rate of florets declines markedly, protein is lost, free amino acids increase and ammonia can accumulate [2]. In freshly harvested asparagus spears fluctuation in the activity of PAL, which catalyzes the conversion of L-phenylalanine to trans-cinnamic acid, is thought to play an important role in lignin synthesis and, therefore, toughening [7]. Major postharvest deterioration of asparagus spears occurs within $24 \mathrm{~h}$ of harvest [3-8]; thus, an understanding of the underlying enzymatic changes occurring in harvested spears may help us to understand and overcome early postharvest deterioration.

Recently, tremendous progress has been made in characterization of the processes involved in postharvest deteriora-

*Address correspondence to this author at the Bioproducts and Bioprocesses Division, Lethbridge Research Centre, Agriculture and Agri-Food Canada, Lethbridge, Alberta T1J 4B1, Canada; E-mail: bhowmikp@agr.gc.ca tion of asparagus spears. Molecular studies, especially those concerning postharvest changes in tips of harvested asparagus spears $[8,9]$, have shown asparagine synthetase (AS) gene expression during storage may play a role in the underlying regulatory mechanism of tissue degredation, and may provide opportunities for regulating the shelf life. Most studies, however, have concentrated on quality loss of stored asparagus, and there has been little enzymatic analysis in relation to postharvest deterioration. As the first step towards understanding and therefore controlling the postharvest deterioration of asparagus spears during storage, we examined the changes in AI, SS, GS and PAL activity in relation to changes in sugar content, ammonia accumulation and fiber content in both top and bottom portions of the spears.

\section{MATERIALS AND METHODS}

\section{Plant Material and Storage}

Green asparagus spears (Asparagus officinalis L. cv. Welcome) manually harvested from a commercial crop in Miki-cho, Ikenobe, Kagawa, Japan were obtained directly from a packing house. This cultivar was selected due to its adaptation to moderate cooler conditions and availabilty throughout the country. Spears were hand harvested and trimmed to approximately $25 \mathrm{~cm}$ length. Straight, undamaged spears with closed bracts and with no obvious signs of disease were put in plastic bags and held at $25^{\circ} \mathrm{C}$ for up to 5 days. At harvest (initial) and at $24 \mathrm{~h}$ intervals the spears were weighed, breaking force was measured and the tissue frozen at $-30^{\circ} \mathrm{C}$ for sugar, ammonia and enzyme analysis.

\section{Enzyme Extraction for Acid Invertase}

Each spear was cut into two equal halves (designated as top and bottom portions) just before extraction. Approxi- 
mately $10 \mathrm{~g}$ of sample from each portion was mixed with $1 \%$ of polyvinylpolypyrrolidone (PVPP) and $1 \mathrm{~g}$ sea sand. The sample was then homogenized using a cooled mortar and pestle with $10 \mathrm{ml}$ of $0.2 \mathrm{M} \mathrm{C}-\mathrm{P}$ buffer ( $\mathrm{pH} 5.0$ ). The resulting homogenate was then filtered through four layers of cotton cloth and the filtrate was centrifuged at $11000 \mathrm{x} g$ for 10 min. The total supernatant was dialyzed with 40 times diluted 0.2 M C-P buffer ( $\mathrm{pH}$ 5.0) for $12 \mathrm{~h}$ and the inner solution was designated as the soluble fraction. All extraction procedures were carried out at $0-4^{\circ} \mathrm{C}$ followed immediately by the enzyme assays.

\section{Enzyme Assays for Acid Invertase}

The standard assay medium for acid invertase consisted of $0.2 \mathrm{ml}$ of $0.2 \mathrm{M} \mathrm{C}$-P buffer ( $\mathrm{pH} 5.0$ ), $0.1 \mathrm{ml}$ of $0.5 \mathrm{M} \mathrm{su}-$ crose, $0.1 \mathrm{ml}$ of water and $0.1 \mathrm{ml}$ of crude enzyme solution. The control contained distilled water instead of sucrose. The assay mixture was incubated at $45^{\circ} \mathrm{C}$ for $15 \mathrm{~min}$. After the reaction, assay mixture was neutralized with $0.1 \mathrm{~N} \mathrm{NaOH}$. A coloring Somogyi's copper reagent was added and the mixture was heated for $10 \mathrm{~min}$ in boiling water. The amount of reducing sugars was estimated by the method of Somogyi [10]. Soluble protein content was determined by the method of Lowry [11] using bovine serum albumin as the standard. The enzyme activity was expressed as the amount of glucose produced per minute per milligram of protein.

\section{Enzyme Extraction for Sucrose Synthase}

Approximately $10 \mathrm{~g}$ of sample from each portion was mixed with $1 \%$ of PVPP and $1 \mathrm{~g}$ sea sand. The sample was then homogenized with $10 \mathrm{ml}$ of $0.2 \mathrm{M} \mathrm{K}-\mathrm{P}$ buffer $(\mathrm{pH} 7.8)$ containing $10 \mathrm{mM}$ ascorbate, $15 \mathrm{mM} \mathrm{MgCl}_{2}, 1 \mathrm{mM}$ EDTA and $1 \mathrm{mM}$ dithiothreitol (DTT) using a cooled mortar and pestle. The resulting homogenate was then filtered through four layers of cotton cloth and the filtrate was centrifuged at $11000 \mathrm{x} g$ for $20 \mathrm{~min}$. The total supernatant was dialyzed with 40 times diluted $0.2 \mathrm{M} \mathrm{K-P}$ buffer $(\mathrm{pH} 7.8)$ for $16 \mathrm{~h}$ and the inner solution was used as the crude enzyme. All extraction procedures were carried out at $0-4^{\circ} \mathrm{C}$.

\section{Enzyme Assays for Sucrose Synthase}

$\mathrm{SS}$ activity was assayed at $37^{\circ} \mathrm{C}$ by the method described by Hubbard [12] with slight modifications. Reaction mixtures $(70 \mu \mathrm{l})$ contained $50 \mathrm{mM}$ Hepes- $\mathrm{NaOH}$ buffer $(\mathrm{pH} 7.5)$, $15 \mathrm{mM} \mathrm{MgCl}_{2}, 25 \mathrm{mM}$ fructose and $25 \mathrm{mM}$ UDP glucose. The mixtures were incubated for $30 \mathrm{~min}$ at $37^{\circ} \mathrm{C}$ and the reaction was terminated with the addition of $70 \mu \mathrm{l}$ of $30 \%$ $\mathrm{KOH}$. Enzyme blanks were terminated with $\mathrm{KOH}$ at 0 min. Tubes were kept at $100^{\circ} \mathrm{C}$ for $10 \mathrm{~min}$ to destroy any unreacted fructose or fructose-6-phosphate. After cooling, $2 \mathrm{ml}$ of anthrone reagent (150 mg anthrone with $100 \mathrm{ml}$ of $15 \%$ $\mathrm{H}_{2} \mathrm{SO}_{4}$ ) was added and incubated in a $40^{\circ} \mathrm{C}$ water bath for 15 min. After cooling color development was measured at 620 $\mathrm{nm}$. The soluble protein content was determined by the method of Lowry [11] using bovine serum albumin as the standard. The enzyme activity was measured as $\mu$ mole of sucrose produced per min per mg protein.

\section{Determination of Soluble Sugar Content}

About $7.5 \mathrm{~g}$ of asparagus sample (for each portion) was mixed with $1 \mathrm{~g}$ sea sand and homogenized in a cooled mortar and pestle. Twenty five $\mathrm{ml}$ of distilled water was added to the homogenate and centrifuged at $11000 \mathrm{x} g$ for $10 \mathrm{~min}$. The mixture was filtered through a cellulose nitrate membrane filter $(0.45 \mu \mathrm{m}$ pore size $)$. Soluble sugars were analyzed by HPLC using a stainless steel column (10.7 mm ID x $30 \mathrm{~cm}$ ) packed with silica gel (gel pack C610). The mobile phase (filtered water) was pumped through the column at a flow rate of $1.0 \mathrm{ml} / \mathrm{min}$. The pressure was adjusted to $14-15$ $\mathrm{kg} / \mathrm{cm}^{2}$ and the temperature to $60^{\circ} \mathrm{C}$. A refractive index (RI) monitor (Hitachi L-3300) was used for detection. Sucrose, glucose and fructose were identified by their retention times and were quantified according to standards.

\section{GS and Ammonia Assay}

GS activity was measured in a total volume of $1.0 \mathrm{ml}$. The assay mixture contained $80 \mathrm{mM}$ L-glutamate-Na, 500 $\mathrm{mM}$ Tricine-KOH Buffer ( $\mathrm{pH}$ 7.0), $600 \mathrm{mM} \mathrm{NH} \mathrm{NH}_{2} \mathrm{OH}, 200$ $\mathrm{mM} \mathrm{MgSO}_{4} \cdot 7 \mathrm{H}_{2} \mathrm{O}, 10 \mathrm{mM}$ Diethylenetriamine pentaacetic acid (DTPA), $80 \mathrm{mM} \mathrm{ATP}$ and $800 \mathrm{mM}$ mercaptoethanol. After incubating at $35^{\circ} \mathrm{C}$ for $8 \mathrm{~min}$, the reaction was stopped by adding $1 \mathrm{ml}$ ferric reagent $\left(25 \mathrm{ml} \mathrm{FeCl}_{3} 6 \mathrm{H}_{2} \mathrm{O}, 50 \mathrm{ml} \mathrm{HCl}\right.$ and $20 \mathrm{ml}$ TCA). GS activity was measured using a double beam spectrophotometer (Shimadzu model UV-150-02) at $540 \mathrm{~nm}$. For assay of ammonia $5 \mathrm{~g}$ samples from each portion were extracted with $10 \%$ Trichloroacetic acid and centrifuged at $11000 \mathrm{x}$ g for $10 \mathrm{~min}$ as described by Kun and Kearney (1974). Ammonia content of the supernatant was determined from a triplicate $500 \mu \mathrm{l}$ sample by adding $200 \mu \mathrm{l}$ $0.5 \mathrm{M}$ Tris-buffer ( $\mathrm{pH} 8.0$ ), $100 \mu 10.1 \mathrm{M} 2$-oxoglutarate solution $(\mathrm{pH} 7.4), 30 \mu 18 \mathrm{mM} \beta-\mathrm{NADH}$ solution, and $150 \mu \mathrm{l}$ distilled water. The absorbance was recorded at $340 \mathrm{~nm}$ against a reagent blank.

\section{Toughness Strength Measurement}

Toughness was measured rheologically based on the measurement of resistance to pressure or shearing. The breaking force to indicate the fiber content in spears was determined with a creep meter Yamaden Rheoner, Model RE-3305) equipped with software Ver. 2.0 for automatic analysis. The thickness of the blade was $0.04 \mathrm{~mm}$ and it sheared at the rate of $1 \mathrm{~mm}$ per second with a pressure of 20 kgf. Spears were cut into two equal pieces and breaking force readings were made separately in the mid point of each section.

\section{Extraction and Assay of PAL Activity}

Two $\mathrm{g}$ of spear tissues were homogenized at $2{ }^{\circ} \mathrm{C}$ with a mortar and pestle in $10 \mathrm{ml}$ of $0.1 \mathrm{M}$ borate buffer, $\mathrm{pH}$ 8.8 and $1.0 \mathrm{~g}$ PVPP. A further $10 \mathrm{ml}$ of the buffer was added to the homogenate which was then centrifuged at $11000 \mathrm{xg}$ rpm for $20 \mathrm{~min}$ and the supernatant was used for enzymatic assays. Protein concentration was measured by Lowry [11] method. PAL activity was determined spectrophotometrically by measuring the increase in $\mathrm{A}_{290}$ due to the formation of trans-cinnamic acid. The reaction mixture consisted of 50 $\mathrm{mM}$ borate buffer, $\mathrm{pH} 8.8,20 \mathrm{mM}$ L-phenylalanine and the enzyme preparation in a total volume of $3 \mathrm{ml}$. A sample without L-phenylalanine was used as a blank. The activity was expressed as nmol trans-cinnamic acid formed per $\mathrm{h}$ per $\mathrm{mg}$ of protein. 


\section{RESULTS}

\section{Acid Invertase Activities}

In both the top and bottom portions soluble acid invertase activity slightly increased during first day of storage and after that it decreased after second day gradually up to five days (Fig. 1). The top portion of the spear showed a significantly lower soluble acid invertase activity than the bottom portion.

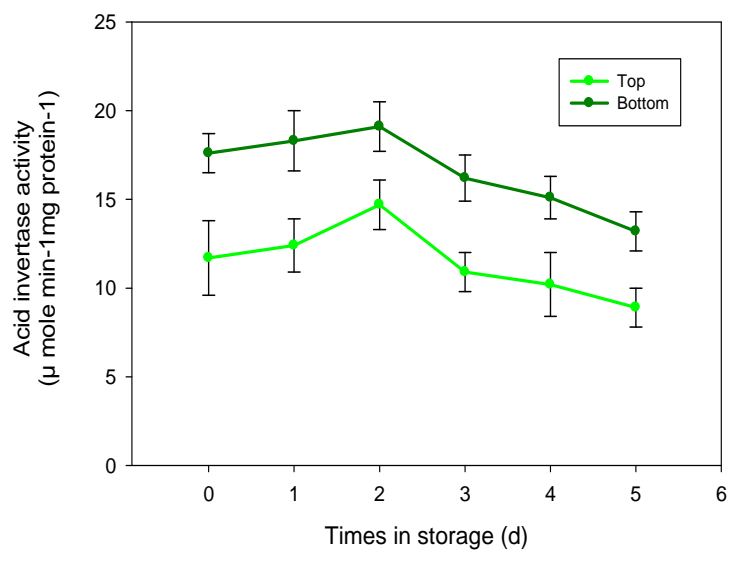

Fig. (1). Changes in acid invertase activity during storage at $25^{\circ} \mathrm{C}$ of asparagus spears. Each point represents the mean of three replicates and bars show SE.

\section{Sucrose Synthase Activity}

Sucrose synthase activity was also higher in the bottom portion than in the top (Fig. 2). In both the top and bottom portions sucrose synthase activity declined from the first day of storage. The rates of decline increased on the third day.

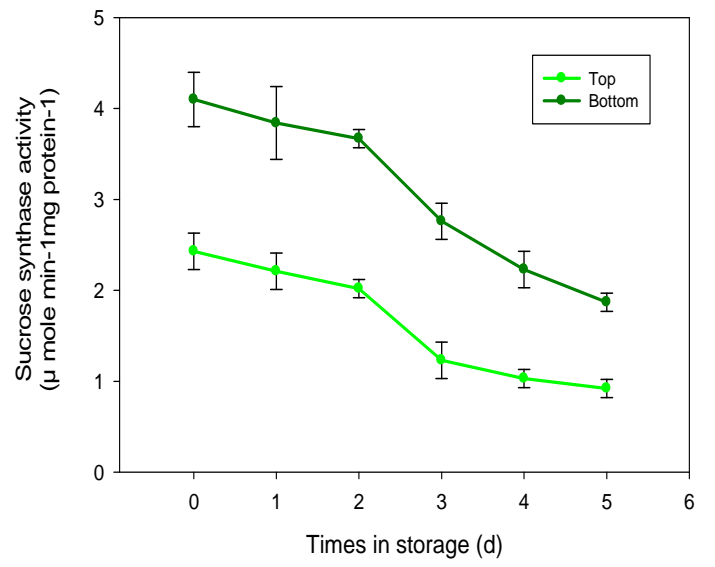

Fig. (2). Changes in sucrose synthase activity during storage at $25^{\circ} \mathrm{C}$ of asparagus spears. Each point represents the mean of three replicates and bars show SE.

\section{Soluble Sugars}

Among the three sugars, sucrose was present only in trace amounts, and fructose content always remained higher than that of glucose in both portions of the spears (Fig. 3). All sugars started to decrease continuously on the first day.
Sucrose content was negatively correlated with invertase and sucrose synthase in both the top and bottom portions ( $\mathrm{r}$ values are not shown).

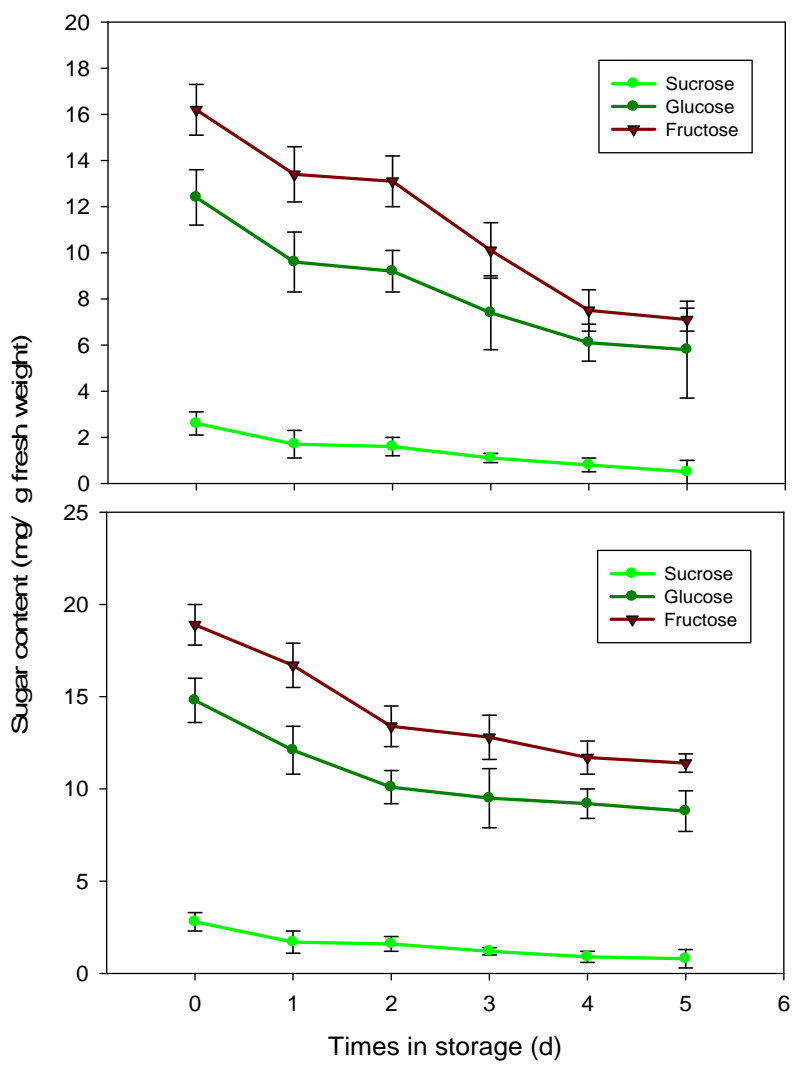

Fig. (3). Changes in soluble sugar content in the top (A) and bottom (B) portions of asparagus spears during storage at $25^{\circ} \mathrm{C}$.

\section{Ammonia Accumulation}

A general increase in ammonia content for both top and bottom portions of spears was observed after harvest (Fig. 4). Ammonia contents increased to about $40 \%$ of initial level after 3 day storage and reached about $60 \%$ of the initial level at the end of 5 day storage period. Higher (almost double) content of ammonia was found in the top portion than in the bottom portion of the spears.

\section{GS Activity}

GS activity began to decline at harvest and continued throughout the storage period in both top and bottom portions (Fig. 5). After five days storage period the activity in the top and bottom portions declined to about $22 \%$ and $24 \%$ of the initial level respectively. The GS activity in the top portion was significantly higher than in the bottom portion of the spears.

\section{Strength of Spears}

Strength of the spears, which may reflect fiber content, increased in both top and bottom portions throughout the experimental period (Fig. 6). Although fiber development in both top and bottom portions followed similar patterns, the 
breaking force was greater in the bottom than in the top portion.

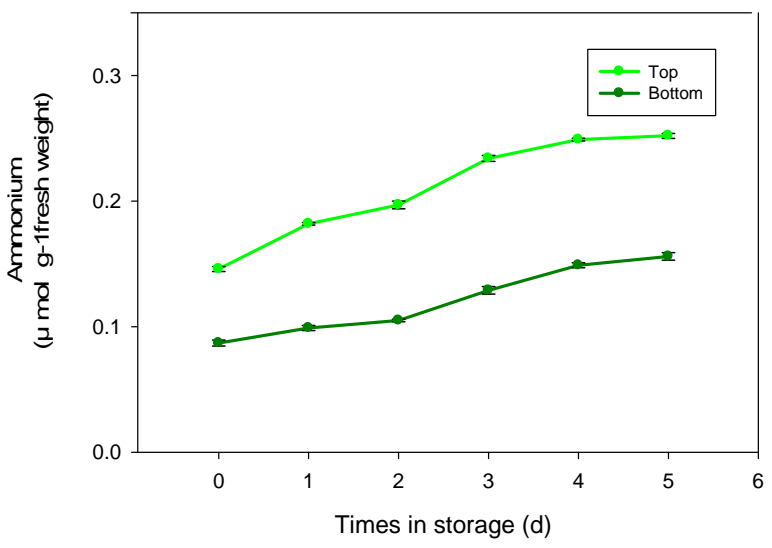

Fig. (4). Ammonia content in the top and bottom portions of the spears. Each point represents the mean of three replications. Vertical bars indicate SE.

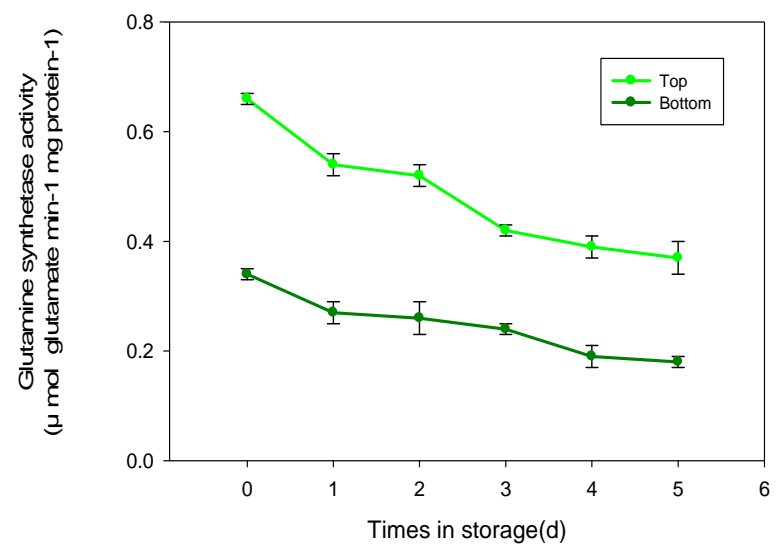

Fig. (5). Time courses of GS activity in the top and bottom portions of the spears held at $25^{\circ} \mathrm{C}$. Each point represents the mean of three replications. Vertical bars indicate SE

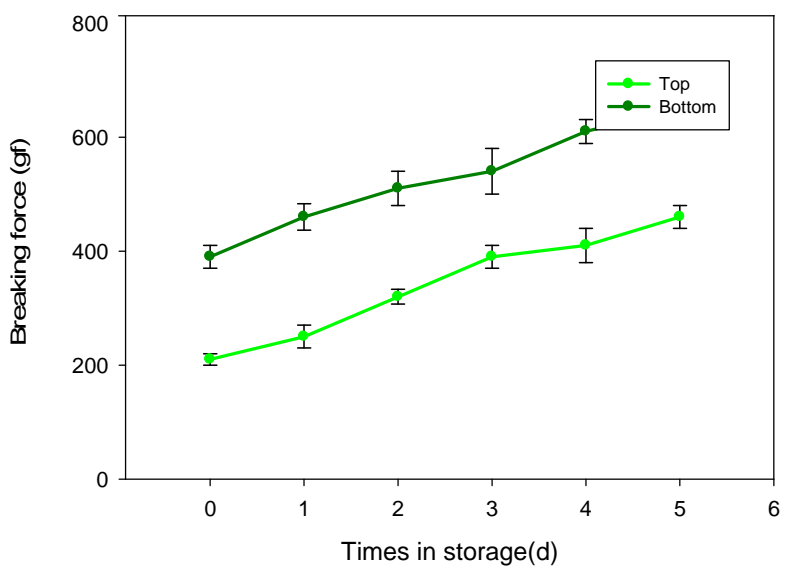

Fig. (6). Changes in fiber content in the top and bottom portions of asparagus spears.

\section{PAL Activity}

Fig. (7) shows the development of PAL activity in both top and bottom portions of asparagus spears. Increase in activity continued until third day resulting in $90 \%$ and $130 \%$ increase over the initial level in top and bottom portions, respectively. Thereafter, the activity started to decline.

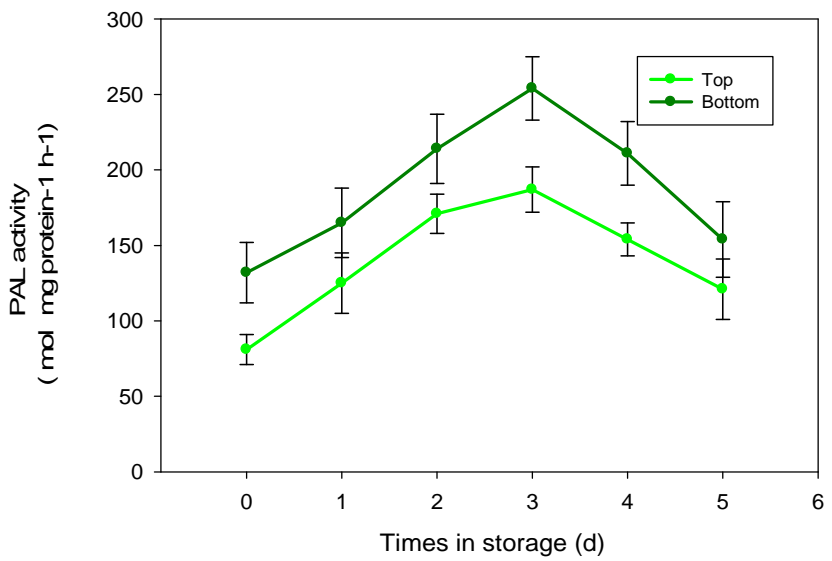

Fig. (7). Changes in PAL activity in the top and bottom portions of asparagus spears.

\section{DISCUSSION}

Fructose and glucose were the major soluble carbohydrates in asparagus spears during storage. Sucrose was found in trace amount. All the three sugars continuously decreased from the first day. This result differs from earlier work [4] where sucrose was the most abundant sugar. Given that the sucrose level drops very rapidly after harvest, it is likely that the discrepancies are due to processing delay and a 5 degree higher storage temperature $\left(25^{\circ} \mathrm{C}\right)$ which was selected to simulate retail display in the super market during spring and summer season. Soluble acid invertase activity was highest in the top portion because of the presence of rapidly growing tissues in that region. Acid invertases are commonly found in rapidly growing and expanding zones of fruit [12], stems [13], leaves [14], and roots [15], where they are said to provide hexoses for cell wall synthesis and to play a major role in maintaining the source-to-sink gradient in sucrose concentration by rapidly hydrolysing incoming sucrose. The differences in enzyme activity between top and bottom portions were because of the diversity of tissue maturity in asparagus spears. The top contains rapidly dividing meristematic cells whereas the bottom comprises more mature lignifying tissue [16]. Initially the acid invertase activity increased in storage and thereafter it gradually declined. The activities of sucrose synthase was generally low compared with acid invertase. Overall, enzyme activities declined up to five days of storage. Our enzyme activity data support the view that the sucrose synthase pathway is important in asparagus spears during storage and the differences in sugar composition are associated with differences in enzyme activities.

Ammonia is toxic to plant cells at high concentrations, and is normally assimilated if produced within the plant [17]. The accumulation of ammonia in senescing leaves has been 
shown to coincide with almost complete disappearance of GS [18]. In the present study we observed the same trend in which GS activity declined in both top and bottom portions of the spears with an increased ammonia accumulation to about $60 \%$ after 5 day storage period. Hurst and Clark [19] reported $30 \%$ decline of total GS activity in harvested spear tips after 5 day storage at $20^{\circ} \mathrm{C}$. The levels of plastid GS activity, polypeptide and mRNA all declined in the tips of harvested asparagus spears [20]. It has been reported that plastid GS has a role in assimilating ammonia produced during photorespiration in higher plants [21]. Hurst et al. [4] reported that although about $65 \%$ of tip GS activity was lost when spears were held at $20^{\circ} \mathrm{C}$, ammonia accumulation was not due to limiting GS levels. They have studied postharvest inhibition of glutamine synthetase using Phosphinothricin (PPT; 40 and $200 \mathrm{ppm}$ ) which reduced GS activity by $50 \%$ and 80 $\%$, respectively, but did not increase ammonia accumulation. Ammonia accumulation was only enhanced, when greater than $95 \%$ of GS was inhibited. Thus, it seems that there is a critical level of GS activity necessary for the postharvest life of asparagus, and that under normal postharvest conditions, this critical level is exceeded and is more than the requirement of ammonia salvage. It is likely that ammonia accumulation results from a shortage of carbon skeletons required for its assimilation, i.e. the demand for respiratory carbon ultimately outstrips the availability of carbon for ammonia reassimilation, and ammonia accumulation ensues.

Therefore, it can be concluded that the increase in ammonia content and decrease in total GS activity in both top and bottom portions of the spears is a response to significant stress after harvest. Perhaps as a consequence of general metabolic decline occurring at this time [2] or may be the consequence of autophagic process [22] induced by carbohydrate deprivation.

The development of PAL activity in asparagus spears was similar in a number of respects to other wound induced tissue systems [23-24]. There was an increase in PAL activity in both top and bottom portions of the spears which continued for about 3 days. After that PAL activity started to decline. Although PAL activity in both top and bottom portions followed almost the same pattern the activity was higher in bottom than top portions. High PAL activity associated with bottom portion, or tissue near to cut surfaces, such as we observed, has been noted previously [22-25]. The basal tissue of the asparagus is highly lignified and PAL activity is known to be correlated with the degree of lignification in many tissues [26-27].

Our results revealed that activity of PAL increased in harvested asparagus until 3 days of storage at $25^{\circ} \mathrm{C}$ and afterwards it started to decline although the strength determined as breaking force was still increasing. The increase in strength after 3 days might be due to the higher activity of other lignin-specific enzymes like peroxidase and cinnamyl alcohol dehydrogenase. Further research is necessary to investigate the role of other lignin-specific enzymes controlling the toughness of asparagus.

\section{REFERENCES}

[1] Li WX, Zhang M, Yu HQ. Study on hypobaric storage of green asparagus. J Food Eng 2006; 73: 225-30.
[2] King GA, Woollard DC, Irving DE, Borst WM. Postharvest Physiological changes in asparagus spear tips. Physiol Plant 1990; 80: 393-400

[3] Bhowmik PK, Matsui T, Ikeuchi T, Suzuki H. Changes in storage quality and shelf life of green asparagus over an extended harvest season. Postharvest Biol Technol 2002; 26: 323-28.

[4] Hurst PL, Hyndman LM, Hannan PJ. Sucrose synthase, invertase andsugars in growing asparagus spears. New Zealand J Crop Hort Sci 1993; 21: 331-36.

[5] Lill RE, King G, O’Donoghue EM. Physiological changes in asparagus spears immediately after harvest. Sci Hortic 1990; 44: 19199

[6] King GA, Henderson KG, O’Donoghue EM, Martin W, Lill RE. Flavour and metabolic changes in asparagus during storage. Sci Hortic 1988; 36: 183-90.

[7] Campbell MM, Ellis BE. Fungal elicitor-mediated responses in pine cell cultures. I. Induction of phenylpropanoid metabolism. Planta 1992; 186: 409-17.

[8] King GA, Davies KM. Identification, cDNA cloning, and analysis of mRNAs having altered expression in tips of harvested asparagus spears. Plant Physiol 1992; 100: 1661-69.

[9] Bhowmik PK, Matsui T. Changes in the activity and expression of 1-Aminocyclopropane-1-Carboxylate (ACC) Synthase, ACC Oxidase, and Phenylalanine Ammonia-Lyase in Asparagus Spears in response to Wound- Induced Ethylene synthesis. HortScience 2004; 39(6): $1074-78$

[10] Somogyi M. Notes on sugar determination. J Biol Chem 1952; 195 : 19-23.

[11] Lowry OH, Rosebrough NJ, Farr A, Rendall LR. Protein measurement with folin-phenol reagent. J Biol Chem 1951; 193: 265-75.

[12] Hubbard NL, Pharr DM. Developmental changes in carbohydrate concentration and activities of sucrose metabolizing enzymes in fruirs of two Capsicum annum L. genotypes. Plant Sci 1992; 86: 33-9.

[13] Sehtiya HL, Dendsay JPS, Dhawan AK. Internodal invertases and stalk maturity in sugarcane. J Agric Sci 1991; 116: 239-43.

[14] Nielson TH. Differences in fructose-2, 6-biphosphate metabolism between sections of developing barely leaves. Physiol plaantarum 1992; 84: 577- 83 .

[15] Getz HP. Activity of cell wall bound acid invertase of mature red beet tisue. Plant Physiol Biochem 1991; 29: 585-93.

[16] Lipton WJ. Postharvest biology of fresh asparagus. In: Janick J, Ed. Horticultural reviews. Timber Press, Inc. Portland, Oregon, USA 1990; Vol. 12: 69-149.

[17] Miflin BJ, Lea PJ. Ammonia assimilation and amino acid metabolism. In: Boulter D, Parthier B Eds. Encyclopedia of Plant Physiology. Springer Verlag, Berlin 1982; Vol. 14 A: 5-64.

[18] Peters KMU. Van Laere. AJ. Ammonium and amino acid metabolism in excised leaves of wheat (Triticum aestivum). Physiol Plant 1992; 84: 243-49.

[19] Hurst PL, Clark CJ. Postharvest changes in ammonium, amino acids and enzymes of amino acid metabolism in asparagus spear tips. J Sci Food Agric 1993; 63: 465-71.

[20] Downs CG, Borst WM, Hurst PL and Stevenson DG. Isoforms of Glutamine synthetase in asparagus spears: The cytosolic enzyme increases after harvest. Plant Cell Environ 1994a; 17: 1045-52.

[21] Edwards JW, Coruzzi GM. Photorespiration and light act in concert to regulate the expression of the nuclear gene for chloroplast glutamine synthetase. Plant Cell 1989; 1: 241-48.

[22] Engelsma G. Photo-induction of phenylalanine deaminase in gherkin seedlings. III. Effects of excision and irradiation on enzyme development in hypocotyls segments. Planta 1968; 82: 355-68.

[23] Rubery PH, Fosket DE. Changes in phenylalanine ammonia -lyase activity during xylem differentiation in coleus and soybean. Planta 1969; 87: 54-62.

[24] Kato M, Kamo T, Wang R, et al. Wound-induced ethylene synthesis in stem tissue of harvested broccoli and its effect on senescence and ethylene synthesis in broccoli florets. Postharvest Biol Technol 2002; 24: 69-8.

[25] Goldstein LD, Jennings PH, Marsh HVJr. L-phenylalanine ammonia-lyase activity in asparagus spears: Effects of excision and incubation. Plant Cell Physiol 1972; 13: 783-93. 
[26] Higuchi T. Role of phenylalanine deaminase and tyrase in the lignification of bamboo. Agr Biol Chem 1966; 30: 667-73.
[27]

Yoshida S, Shimokoriyama M. Studies on phenylalanine deaminase in buckwheat plant. Bot Mag (Tokyo) 1965; 78: 14-19.

Received: March 19, 2008

Revised: June 5, 2008

Accepted: August 25, 2008

(C) Bhowmik et al.; Licensee Bentham Open.

This is an open access article licensed under the terms of the Creative Commons Attribution Non-Commercial License (http://creativecommons.org/licenses/ by-nc/3.0/) which permits unrestricted, non-commercial use, distribution and reproduction in any medium, provided the work is properly cited. 